\title{
PENGEMBANGAN MODEL PEMBELAJARAN BERBASIS CTL UNTUK MENINGKATKAN KOMPETENSI MENGGAMBAR BERBANTUAN KOMPUTER (CAD) SISWA SMK
}

\author{
Febrianto Amri Ristadi ${ }^{1}$, Yatin Ngadiyono ${ }^{2}$ \\ ${ }^{1,2}$ Pendidikan Teknik Mesin, Fakultas Teknik Universitas Negeri Yogyakarta \\ amri@uny.ac.id
}

\begin{abstract}
This research aims to define a construct of CTL-based learning model on CAD subject. The learning model is intended for vocational high school students to improve their CAD competence. The research method being used was Research and Development methods implementing Dick and Carrie's approach. The research was carried out in Bantul and Kulonprogo district. The subject was SMK students underwent CAD subject learning. The result of large scale test shows that the CAD learning model is appropriate to be implemented in the CAD teaching and learning. The modul gained a strong positive response from the students in the functional and benefit aspects, with an average score of 24.42. The modul also gained a strong positive response from the attractiveness aspect with an average score of 37.73. Students also found that it is very appropriate in the learning material aspect, shown by an average score of 30.70. The CAD learning methods can be implemented by following the steps of defining Basic Competencies, subject materials and objects, motivating the students by assosiating the learning material with environmental context, determining heterogeneous group and administering task, group discussion, individual task, assessment, reflection and feedbacks. The CAD learning implementing the CTL-based modul evidently improves the students' achievement by 19\%, from 71.18 to 84.64.
\end{abstract}

Keywords: contextual teaching learning, computer aided design, mechanical drawing, learning model

\begin{abstract}
ABSTRAK
Tujuan penelitian ini adalah menemukan konstruksi model pembelajaran berbasis CTL pada mata diklat CAD. Metode penelitian yang diterapkan adalah penelitian pengembangan dengan pendekatan Dick \& Carie. Penelitian dilakukan di Bantul dan Wates, Kulon Progo. Subyek penelitian adalah siswa SMK yang menempuh mata diklat CAD. Hasil uji coba pada skala besar menunjukkan bahwa modul CAD layak untuk diterapkan dalam uji coba pembelajaran CAD. Modul mendapatkan kategori respons sangat layak dari siswa untuk: (a) aspek fungsi dan manfaat dengan skor rerata 24,42, (b) aspek kemenarikan dengan skor rerata 37,73, (c) aspek materi pembelajaran dengan skor rerata 30,70. Metode pembelajaran CAD ditempuh dengan urutan sebagai berikut: (1) menentukan KD, (2) menentukan materi, (3) menentukan benda/obyek, (4) memotivasi dengan mengaitkan materi ajar dengan konteks lingkungan, (5) penentuan kelompok heterogen, pemberian tugas, (6) diskusi kelompok, (7) tugas mandiri, (8) penilaian, (9) refleksi hasil dan umpan balik. Pembelajaran CAD menggunakan modul berbasis CTL dapat meningkatkan prestasi sebesar 19\%, atau dari 71.18, menjadi 84.64.
\end{abstract}

Kata kunci: CTL, CAD, gambar teknik, model pembelajaran

\section{PENDAHULUAN}

Pendidikan merupakan modal penting dan mendasar untuk mewujudkan suatu bangsa yang kokoh dan terlepas dari keterpurukan. Kebutuhan akan sumber daya manusia yang kreatif dan profesional nampak menjadi kebutuhan mendesak. Terlebih dengan diberlakukannya pasar bebas ASEAN tahun
2015 mengakibatkan adanya perubahan struktur ketenagakerjaan (Paulus, 2014) dan standar sertifikasi yang mempunyai tuntutan yang semakin tinggi. Untuk itu sistem pendidikan di Indonesia perlu dipersiapkan menjadi sistem yang tangguh dan bernilai jual tinggi dengan berbasis pada potensi lokal sebagai penangkal terhadap ketergantungan dan inferioritas pada dunia luar. 
Sekolah Menengah Kejuruan (SMK) adalah salah satu jenjang pendidikan di Indonesia yang menitik beratkan peserta didiknya kompeten pada bidang tertentu. Dalam perkembangannya SMK dituntut untuk mampu menciptakan Sumber Daya Manusia (SDM) yang dapat berakselerasi dengan kemajuan IPTEK. SMK sebagai pencetak lulusan yang siap kerja harus membekali peserta didiknya dengan kemampuan yang sesuai di bidangnya, oleh karena itu pada saat proses belajar mengajar harus lebih di tingkatkan lagi baik itu sarana dan prasarananya maupun media pembelajarannya yang efektif sehingga mampu memudahkan siswa dalam menyerap pelajaran tersebut.

Pembelajaran di SMK bertujuan untuk mempersiapkan siswa memasuki dunia kerja, di mana mata pelajaran dibagi dalam 3 kelompok yaitu pelajaran adaptif, normatif dan produktif. Salah satu mata pelajaran yang menjadi media komunikasi adalah gambar teknik. Gambar teknik adalah mata pelajaran produktif dan ditingkat lanjut dilakukan dengan menggambar berbantuan komputer atau biasa disebut Computer Aided Design (CAD). Aplikasi CAD mencakup keseluruhan proses desain dan dapat terakomodir dengan cepat dan murah. Hal itu dikarenakan kesalahan dalam proses pembuatan desain dapat dibuat seminimal mungkin dan berimplikasi pada pengurangan waktu dan biaya desain itu sendiri (Liu \& Sorby, 2009). Hal ini sangat membantu dalam dunia industri dan menjadikan proses desain lebih efektif dan efisien.

Penguasaan gambar dengan CAD ini memungkinkan siswa lebih siap dan lebih mudah untuk masuk ke dunia kerja, karena saat ini sebagian besar perusahaan manufaktur sudah menggunakan software untuk membuat gambar manufaktur. Mata pelajaran ini merupakan mata pelajaran yang harus dikuasai oleh siswa kelas 2 dan 3. Namun pada kenyataannya, kompetensi siswa dalam mata pelajaran gambar teknik masih kurang, sehingga banyak siswa yang kesulitan untuk bisa menempuh mata pelajaran gambar teknik dengan baik. Kurangnya kompetensi siswa ini disebabkan oleh banyak hal mulai dari kelemahan metode mengajar dan kurangnya media yang digunakan.

Inovasi, perubahan dan implementasi perlu segera dilakukan dengan berbagai upaya pada pola pembelajaran teknologi. Pertimbangan ini didasarkan pada pengamatan peneliti bahwa karya mahasiswa yang berupa karya teknologi masih di bawah 50\% dari tujuan yang ditetapkan. Kenyataan ini menunjukkan bahwa untuk mengaplikasikan apa yang telah diperoleh mahasiswa dalam teori keteknikan (seperti: mekanika, termodinamika, gambar teknik, dll.) belum memberikan arahan pada kesatuan pemahaman ilmu dan teknologi. Dalam merancang desain mesin atau alat tepat guna dituntut memahami sistem mekanis, kontrol, dan proses manufaktur. Dari uraian di atas, dapat dikatakan bahwa perancang teknik dituntut pemahaman holistis.

Lulusan perguruan tinggi yang berkualitas merupakan salah satu syarat penting memasuki persaingan global. Di mana semakin terbatasnya kesempatan untuk memasuki lapangan kerja bagi perguruan tinggi, baik oleh karena dampak kondisi ekonomi negara maupun otomatisasi di perusahaan/industri di masa mendatang, maka tuntutan agar lulusan perguruan tinggi mampu menciptakan peluang kerja sendiri menjadi faktor kunci. Penciptaan peluang kerja tersebut hanya dapat terwujud apabila mereka mempunyai kompetensi yang tinggi.

Kondisi di lapangan menunjukkan bahwa masih sangat jarang ditemui lulusan perguruan tinggi, khususnya Program Studi Teknik Mesin yang mempunyai kompetensi dengan kualitas tinggi. Hal ini mengindikasikan lemahnya metode pembelajaran yang selama ini dilaksanakan. Persoalannya adalah bagaimana metode pembelajaran tersebut dapat dikembangkan sehingga mampu menghasilkan lulusan yang berkualitas. 


\section{METODE}

Luaran penelitian diharapkan dapat memperbaiki PBM, program dan model pembelajaran yang tengah berjalan di SMK. Oleh karenanya pendekatan yang diambil dalam uji coba dan penerapan menggunakan pendekatan Penelitian Tindakan Kelas (Coats, 2005). Sementara untuk mendapatkan model yang sesuai dengan kurikulum 2013 dilakukan dengan menggunakan metode penelitian dan pengembangan (R\&D). Borg dan Gall (2003: 773) menjelaskan bahwa penelitian dan pengembangan merupakan suatu proses yang digunakan untuk mengembangkan atau memvalidasi produk-produk yang digunakan dalam pembelajaran.

Model pengembangan yang digunakan dalam penelitian ini adalah model dari Dick \& Carey (2015: 6-8), yaitu melalui langkahlangkah: (1) Mengenali tujuan pembelajaran (identifiying an instructional goal), (2) Analisis pembelajaran (conducting an instructional), (3) Mengenali tingkah laku masukan dan karakteristik (identifying entry behaviours and characteristic), (4) Merumuskan tujuan performa (Writing performance objectives), (5) Mengembangkan tes acuan patokan (developing criterion referenced test), (6) Mengembangkan strategi pembelajaran (developing an instructional strategy), (7) Mengembangkan dan memilih materi pembelajaran (developing an instructional materials), (8) Mendesain dan melakukan penilaian formatif (designing and conducting formative evaluation), (9) Memperbaiki atau merevisi (instructional revisions), (10) Mendesain dan melakukan evaluasi sumatif (design and conduct summative evaluation).

Urutan perencanaan dan pengembangan sebagaimana yang dikembangkan oleh Walter Dick \& Lou Carey (2015) adalah sebagaimana ditunjukkan pada Gambar 1.

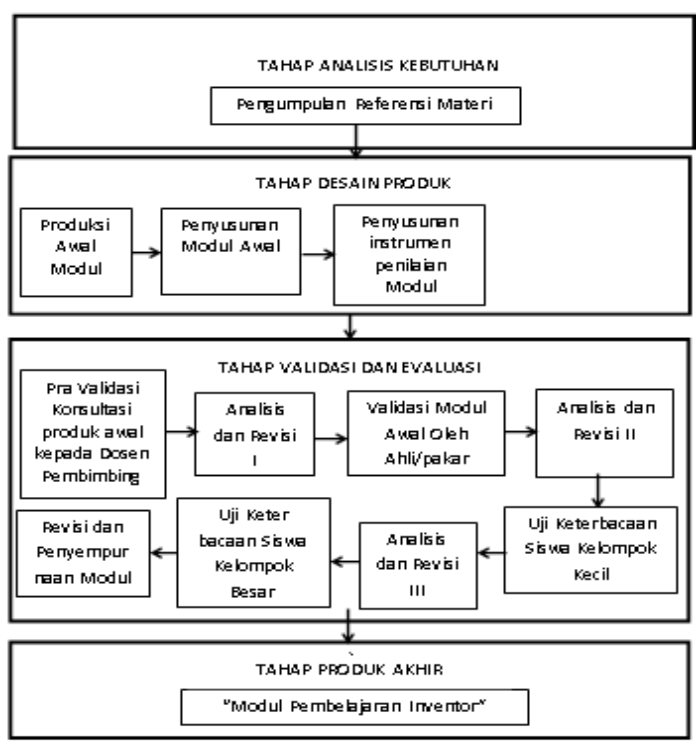

Gambar 1. Prosedur Pengembangan Modul (Diadaptasi dari Dick \& Carey)

\section{HASIL DAN PEMBAHASAN}

Validasi modul dilaksanakan dalam tiga tahapan yaitu: validasi oleh pengajar mata pelajaran $\mathrm{CAD}$, uji coba lapangan skala kecil dan uji coba lapangan skala besar. Uji validasi oleh pengajar mata pelajaran guru Gambar Manufaktur dilakukan di SMK Muhammadiyah 1 Bantul dan SMK Negeri 2 Pengasih. Berikut adalah hasil mengenai kelayakan modul pembelajaran CAD ditunjukkan pada Tabel 1 .

Tabel 1. Hasil uji validasi pengajar CAD

\begin{tabular}{|c|c|c|c|c|}
\hline No & Aspek & Hasil & Interval & Kategori \\
\hline 1. & Fungsi/manfaat & 23,00 & $\mathrm{X} \geq 21$ & $\begin{array}{l}\text { Sangat } \\
\text { layak }\end{array}$ \\
\hline 2. & $\begin{array}{l}\text { Tampilan } \\
\text { cover }\end{array}$ & 11,50 & $9>X \geq 7,5$ & Layak \\
\hline 3. & Materi modul & 39,00 & $X \geq 33$ & $\begin{array}{l}\text { Sangat } \\
\text { layak }\end{array}$ \\
\hline 4. & $\begin{array}{l}\text { Media } \\
\text { pembelajaran }\end{array}$ & 25,75 & $X \geq 24$ & $\begin{array}{l}\text { Sangat } \\
\text { layak }\end{array}$ \\
\hline
\end{tabular}

Data hasil uji coba lapangan kecil diperoleh dengan cara memberikan modul pembelajaran kepada siswa, mengisi angket yang di dalamnya terdapat kisi-kisi serta pernyataan penilaian. Uji coba ini dilakukan dengan menggunakan instrumen angket yang terdiri dari 30 pernyataan. Jumlah siswa yang ikut uji coba lapangan kecil berjumlah 12 siswa. Hasil uji coba lapangan skala kecil 
mengenai kelayakan modul pembelajaran $\mathrm{CAD}$ ditunjukkan pada Tabel 2.

Tabel 2. Hasil uji lapangan skala kecil

\begin{tabular}{lllll}
\hline No & Aspek & Hasil & Interval & Kategori \\
\hline & Fungsi/manfaat & 30,66 & $\mathrm{X} \geq 27$ & $\begin{array}{l}\text { Sangat } \\
\text { layak }\end{array}$ \\
2. & Kemenarikan & 40,06 & $\mathrm{X} \geq 36$ & $\begin{array}{l}\text { Sangat } \\
\text { layak } \\
\text { 3angat } \\
\text { layak }\end{array}$ \\
\hline
\end{tabular}

Uji keterbacaan kelompok besar dilakukan di Lab Komputer unit 3 SMK Muhammadiyah 1 Bantul. Uji keterbacaan modul kelompok besar diikuti oleh 30 peserta didik kelas XI TP 1 SMK Muhammadiyah 1 Bantul. Peralatan yang dibutuhkan adalah modul, angket, alat tulis sejumlah peserta didik, proyektor dan laptop.

Modul yang digunakan pada uji keterbacaan modul kelompok besar dicetak warna dengan dua sisi (bolak-balik). Uji keterbacaan kelompok besar dilakukan dengan langkah-langkah membagi peserta didik menjadi 2 gelombang pada pembelajaran CAD, dan menyampaikan maksud dan tujuan penelitian. Langkah selanjutnya yaitu membagikan modul dengan jumlah 15 buah kepada peserta didik gelombang pertama, meminta peserta didik mengamati keseluruhan isi modul, membagikan angket penilaian sejumlah peserta didik, meminta peserta didik mengisi angket yang di dalamnya terdapat kisikisi serta pernyataan penilaian, mengumpulkan angket yang telah diisi beserta modulnya, menyampaikan ucapan terima kasih atas kesediaan mengikuti uji coba lapangan skala besar.

Data uji keterbacaan modul kelompok besar terdiri dari tiga aspek penilaian yaitu aspek fungsi dan manfaat, aspek kemenarikan dan aspek materi pembelajaran. Data ini dikaji untuk mengetahui tanggapan peserta didik mengenai kelayakan modul pembelajaran yang dihasilkan serta untuk mengetahui tingkat kelayakan modul yang telah dikembangkan sebelum digunakan dalam lingkup yang sebenar-benarnya. Berikut adalah data hasil uji keterbacaan modul kelompok besar mengenai kelayakan modul pembelajaran CAD (Tabel 3).

Tabel 3. Hasil uji lapangan skala besar

\begin{tabular}{lllll}
\hline No & Aspek & Hasil & Interval & Kategori \\
\hline & Fungsi/manfaat & 24,42 & $\mathrm{X} \geq 21$ & $\begin{array}{l}\text { Sangat } \\
\text { layak }\end{array}$ \\
2. & Kemenarikan & 37,73 & $\mathrm{X} \geq 33$ & $\begin{array}{l}\text { Sangat } \\
\text { layak }\end{array}$ \\
3. & $\begin{array}{l}\text { Materi } \\
\text { pembelajaran }\end{array}$ & 30,70 & $\mathrm{X} \geq 27$ & $\begin{array}{l}\text { Sangat } \\
\text { layak }\end{array}$ \\
\hline
\end{tabular}

Pelaksanaan pada tahap pembelajaran menggunakan model pembelajaran dengan menerapkan modul dan pembelajaran dengan Contextual Teaching and Learning (CTL). Menurut Johnson (2002), pembelajaran CTL terdiri dari 8 komponen, yaitu menjalin koneksi yang syarat makna, pembelajaran yang dapat diatur sendiri, menghasilkan kerja yang signifikan, kolaborasi, berpikir kritis dan kreatif, memberdayakan individu, pencapaian standar yang tinggi seerta menggunakan asesmen yang otentik. Tahapan proses pembelajaran $\mathrm{CAD}$ dengan alur yang disesuaikan dengan pembelajaran CTL ditunjukkan pada Gambar 2. Permasalahanpermasalahan yang muncul pada pelaksanaan awal penelitian yaitu terkait: (1) Menggambar dan memodifikasi gambar 3D dan (2) Menyajikan gambar akhir 2D.

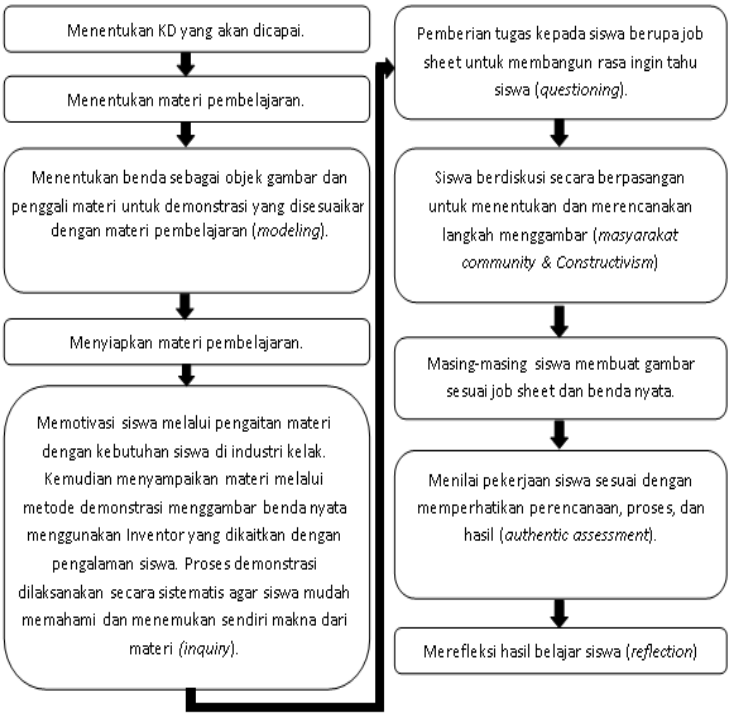

Gambar 2. Alur Pembelajaran CTL Tahap Awal 
Permasalahan yang terkait dengan menggambar dan memodifikasi gambar 3D adalah: (a) Siswa masih terpaku dengan penggunaan langkah secara manual sehingga kurang mampu memanfaatkan fungsi perintah yang ada pada part design, (b) Penentuan langkah dan penggunaan fungsi perintah masih banyak yang kurang efektif, (c) Siswa kurang teliti dalam mengukur benda pada job sheet dan menentukan ukurannya, (d) Beberapa siswa masih belum cukup mahir menggunakan fungsi perintah pada part design, (e) Sumber belajar yang hanya dari guru dirasa sangat kurang mengingat waktu pembelajaran yang hanya $3 \times 45$ menit, (f) Pembelajaran secara berpasangan masih belum efektif, ( $\mathrm{g}$ ) Kompetensi siswa dalam menggambar dan memodifikasi gambar 3D masih kurang dengan rata-rata nilai 71.179 dan siswa yang mendapatkan nilai di atas KKM 7.6 hanya sebesar $28.57 \%$.

Permasalahan lainnya yaitu terkait dengan menyajikan gambar akhir 2D adalah: (a) Siswa sudah terlihat antusias mengikuti kegiatan pembelajaran namun beberapa masih ada yang mengakses internet saat pembelajaran berlangsung, (b) siswa masih belum cukup mahir menggunakan fungsi perintah pada Inventor drawing, sehingga siswa masih perlu dibimbing pada proses menggambarnya, (c) Siswa masih belum lengkap dalam memberikan ukuran dan atribut pada gambar kerja, (d) Layout gambar siswa masih banyak yang belum proporsional, (e) Sebagian besar siswa mengabaikan standar gambar, (f) Sumber belajar yang hanya dari guru dirasa sangat kurang mengingat waktu pembelajaran yang hanya $3 \times 45$ menit, (g) Pembelajaran secara berpasangan masih belum efektif, (h) Kompetensi siswa dalam menyajikan gambar akhir 2D masih kurang dengan rata-rata nilai 68.75 dan siswa yang mendapatkan nilai di atas KKM 7.6 hanya sebesar $14.286 \%$.

Penyusunan rencana tindakan terfokus pada perencanaan pembelajaran pada penelitian pengembangan. Perencanaan yang telah dikonsultasikan dengan guru dengan berdasarkan analisis permasalahan yang muncul pada penelitian tahap awal maka pada akhir materi yang akan dipelajari adalah tentang membuat dan memodifikasi gambar 3D dan gambar akhir 2D dari piston, sehingga kompetensi dasar yang akan dicapai yaitu menggunakan fungsi perintah dalam perangkat lunak CAD untuk membuat dan memodifikasi gambar CAD serta menyajikan gambar detail komponen mesin dengan CAD. Pemilihan piston sebagai objek gambar dikarenakan tingkat kerumitannya yang sudah meningkat dari objek gambar pada tahap awal dan proses penggambaran piston sudah mewakili materi yang akan diajarkan Adapun kegiatan yang dilakukan pada tahap perencanaan ini antara lain sebagai berikut: (1) Merancang tindakan berdasarkan permasalahan pada pra penelitian dengan penerapan model pembelajaran CTL yang kemudian dituangkan pada RPP dan skenario pembelajaran, (2) Membuat rencana pelaksanaan pembelajaran dengan kompetensi dasar menggunakan fungsi perintah dalam perangkat lunak $\mathrm{CAD}$ untuk membuat dan memodifikasi gambar CAD serta menyajikan gambar detail komponen mesin dengan CAD, (3) Membuat skenario pembelajaran yang berisikan kegiatan pembelajaran, tujuan pembelajaran dan langkah pembelajaran, (4) Membagi kelas menjadi 4 kelompok agar siswa aktif berdiskusi dalam memecahkan permasalahan yang ada dengan pembagian kelompok secara merata sesuai kemampuan siswa berdasarkan hasil pra penelitian, (5) Menyiapkan benda sebagai objek gambar beserta job sheet, (6) Menyiapkan lembar penilaian dan lembar pengamatan kegiatan siswa, (7) Memberikan pengarahan kepada pengamat (teman sejawat) terkait teknis pengamatan siswa ketika proses pembelajaran berlangsung.

Kegiatan pembelajaran menggunakan model pembelajaran CTL didasarkan pada tujuh komponen utama pembelajaran CTL. Berikut penjelasan masing-masing komponen pada pelaksanaan pembelajaran tahap akhir: (1) Konstrutivisme (Constructivism) yaitu 
mengembangkan pemikiran bahwa anak akan belajar lebih bermakna dengan bekerja sendiri dan membangun sendiri pengetahuan dan keterampilan barunya dengan cara setelah guru mendemonstrasikan materi tentang membuat gambar 3D dan gambar kerja, siswa disuruh untuk merencanakan gambar sketsa, langkah dan fungsi perintah yang digunakan untuk membuat gambar 3D dan gambar kerja dari piston. (2) Menemukan (Inquiry) yaitu melakukan sejauh mungkin inkuiri untuk semua tema/topik, dengan cara guru mendemonstrasikan menggambar 3D dan membuat gambar kerja secara sistematis mulai dari langkah menggambarnya, pemilihan fungsi perintah yang sesuai dan efektif untuk digunakan sampai proses pembuatannya, agar siswa mampu memahami setiap materi yang diberikan sehingga mampu menemukan sendiri penggunaan fungsi perintah dan langkah kerja untuk membuat gambar 3D dan gambar kerja dari piston. (3) Bertanya (Questioning) yaitu mengembangkan sifat ingin tahu siswa dengan bertanya yaitu dengan cara melalui permasalahan yang dihadapi tiap siswa dalam membuat gambar 3D dan gambar kerja dari piston sesuai dengan benda nyatanya dan job sheet, siswa akan berusaha bertanya untuk memecahkan permasalahan tersebut, baik kepada siswa lain maupun kepada guru. (4) Masyarakat belajar (Learning community) yaitu menciptakan masyarakat belajar melalui pembagian kelompok agar memudahkan siswa saling bertukar pikiran untuk memecahkan permasalahan yang sama dalam membuat gambar 3D dan gambar kerja dari piston. (5) Pemodelan (Modeling) yaitu menggunakan model/objek gambar yang pernah dijumpai siswa yaitu conrod dan botol sebagai media penyampaian materi dan menghadirkan piston sebagai objek gambar atau bahan belajar siswa. (6) Refleksi (Reflection) yaitu refleksi dilakukan pada saat siswa mengerjakan gambar dari piston dan hasil pekerjaan siswa. Dari pekerjaan siswa tersebut dapat diketahui sejauh mana siswa memahami dan mampu menerapkan materi yang disampaikan. (7)
Penilaian sebenarnya (Authentic assessment) yaitu melakukan penilaian yang sebenarnya terhadap pengetahuan dan keterampilan siswa dalam membuat gambar 3D dan membuat gambar kerja dari piston yang tertuang dalam instrumen penilaian dengan menilai proses perencanaan, pengerjaan, hasil pengerjaan, serta waktu pengerjaan. Dari penilaian sebenarnya diperoleh distribusi nilai siswa pada tahap akhir yang dipaparkan pada tahap analisis data.

Pelaksanaan tahap pengembangan yaitu terdiri atas pengambilan hasil-hasil analisis data, interpretasi tentang hasil-hasil tersebut sekaligus rumusan rencana aksi pada pembelajaran. Berikut ini permasalahanpermasalahan yang muncul pada pelaksanaan uji alur pembelajaran hasil penyempurnaan. Permasalahan yang terkait membuat dan memodifikasi gambar 3D yaitu: (a) Sebagian siswa mengabaikan proses perencanaan, (b) Objek gambar yang bentuknya kompleks membuat siswa kebingungan dalam menentukan langkah penggambaran, (c) Siswa masih belum memanfaatkan edit sketch dan edit feature dengan baik, (d) Siswa kurang fokus saat mengikuti pembelajaran karena waktu pembelajaran yang hanya tambahan tatap muka saja, (e) Kompetensi siswa kelas XI TP2 rombel 2 dalam membuat dan memodifikasi gambar 3D ditargetkan meningkat dari rerata nilai ketuntasan minimal, yaitu 76 dan harus lulus $100 \%$.

Permasalahan yang muncul terkait mengenai menyajikan gambar akhir 2D, yaitu: (a) Siswa kurang fokus saat mengikuti pembelajaran karena waktu pembelajaran yang hanya tambahan tatap muka saja dan (b) Kompetensi siswa kelas XI TP2 rombel 2 dalam menyajikan gambar akhir 2D ditargetkan meningkat dari rerata nilai ketuntasan minimal, yaitu 76 dan harus lulus 100\%. Namun demikian kompetensi siswa dalam menggambar dengan sistem CAD yang diperoleh dari hasil penjumlahan kedua kompetensi tersebut dengan bobot $40 \%$ membuat dan memodifikasi gambar 3D dan $60 \%$ menyajikan gambar akhir 2D, diperoleh rata-rata nilai 85.07 dan siswa 
yang mendapatkan nilai di atas KKM 7.6 sudah mencapai $100 \%$.

Berdasarkan permasalahan tersebut, peneliti merumuskan rencana aksi pada pembelajaran setelah tahap akhir antara lain: (a) Masih perlu memberi bimbingan secara lebih intensif pada tiap kelompok, (b) Menekankan kembali pentingnya teknik design intent pada proses menggambar menggunakan sistem $\mathrm{CAD}$, dan (c) Menekankan tentang pemanfaatan penggunaan edit feature dan edit sketch.

Prestasi belajar siswa pada pembelajaran CAD dilihat dari dua kategori yaitu prestasi CAD 3D dan CAD 2D. Data hasil keterampilan menggambar 3D menggunakan Inventor peserta didik dari nilai pretest dan posttest disajikan pada Tabel 4.

Tabel 4. Deskripsi Data Nilai keterampilan menggambar 3D menggunakan Inventor

\begin{tabular}{|c|c|c|c|}
\hline \multicolumn{4}{|c|}{ Statistics } \\
\hline & & Pretest & Posttest \\
\hline \multirow[t]{2}{*}{$\mathrm{N}$} & Valid & 14 & 14 \\
\hline & Missing & 0 & 0 \\
\hline \multicolumn{2}{|l|}{ Mean } & 71.1786 & 84.6429 \\
\hline \multicolumn{2}{|c|}{ Std. Error of Mean } & 2.66727 & 2.33313 \\
\hline \multicolumn{2}{|l|}{ Median } & 71.5000 & 85.0000 \\
\hline \multicolumn{2}{|l|}{ Mode } & 65.00 & $74.00^{\mathrm{a}}$ \\
\hline \multicolumn{2}{|c|}{ Std. Deviation } & 9.97999 & 8.72976 \\
\hline \multicolumn{2}{|l|}{ Variance } & 99.600 & 76.209 \\
\hline \multicolumn{2}{|l|}{ Skewness } & .327 & -.012 \\
\hline \multicolumn{2}{|c|}{ Std. Error of Skewness } & .597 & .597 \\
\hline \multicolumn{2}{|l|}{ Kurtosis } & -.668 & -1.690 \\
\hline \multicolumn{2}{|c|}{ Std. Error of Kurtosis } & 1.154 & 1.154 \\
\hline \multicolumn{2}{|l|}{ Range } & 32.50 & 21.00 \\
\hline \multicolumn{2}{|l|}{ Minimum } & 55.00 & 74.00 \\
\hline \multicolumn{2}{|l|}{ Maximum } & 87.50 & 95.00 \\
\hline \multicolumn{2}{|l|}{ Sum } & 996.50 & 1185.00 \\
\hline \multirow[t]{3}{*}{ Percentiles } & 25 & 64.3750 & 74.0000 \\
\hline & 50 & 71.5000 & 85.0000 \\
\hline & 75 & 78.8750 & 95.0000 \\
\hline
\end{tabular}

a. Multiple modes exist. The smallest value is shown

Berdasarkan data nilai pretest terendah 55, sedangkan nilai tertinggi 87.50 dengan dengan nilai rata-rata pretest sebelum ada modul 71.1786 dengan standard deviation 9.97999 dan mode 65. Jumlah ketuntasan peserta didik dalam satu kelas sebesar $28.57 \%$. Pembelajaran dengan menggunakan modul pendekatan kontekstual menunjukkan nilai posttest dengan nilai terendah 74 sedangkan nilai tertinggi 95.00 dengan dengan nilai ratarata posttest sesudah perlakuan 84.6429 dengan standard deviation 8.72976 dan mode 74 dan 95. Jumlah ketuntasan peserta didik dalam satu kelas sebesar $71 \%$. Berdasarkan perbandingan skewness dan kurtosis nampak bahwa kedua distribusi nampak normal.

Data hasil keterampilan menggambar 2D menggunakan Inventor peserta didik dari nilai pretest dan posttest disajikan seperti pada Tabel 5. Berdasarkan Tabel 5 nilai pretest terendah 74, sedangkan nilai tertinggi 95.00 dengan dengan nilai rata-rata pretest sebelum ada modul 84.6429 dengan standard deviation 8.72976 dan mode 74. Jumlah ketuntasan peserta didik dalam satu kelas sebesar $28.57 \%$. Pembelajaran dengan menggunakan modul pendekatan kontekstual menunjukkan nilai posttest dengan nilai terendah 80 sedangkan nilai tertinggi 90.00 dengan dengan nilai ratarata posttest sesudah perlakuan 85.3571 dengan standard deviation 4.14371 dan mode 85 . Jumlah ketuntasan peserta didik dalam satu kelas sebesar $71 \%$.

Pelaksanaan pembelajaran pada tahap akhir dirasa sudah mampu menerapkan model pembelajaran CTL secara efektif. Hal tersebut dapat dilihat dari meningkatnya hasil belajar siswa dan jumlah kelulusan siswa terhadap KKM mampu mencapai 100\%. Gambar langkah penerapan model pembelajaran CTL yang diajukan seperti pada Gambar 3.

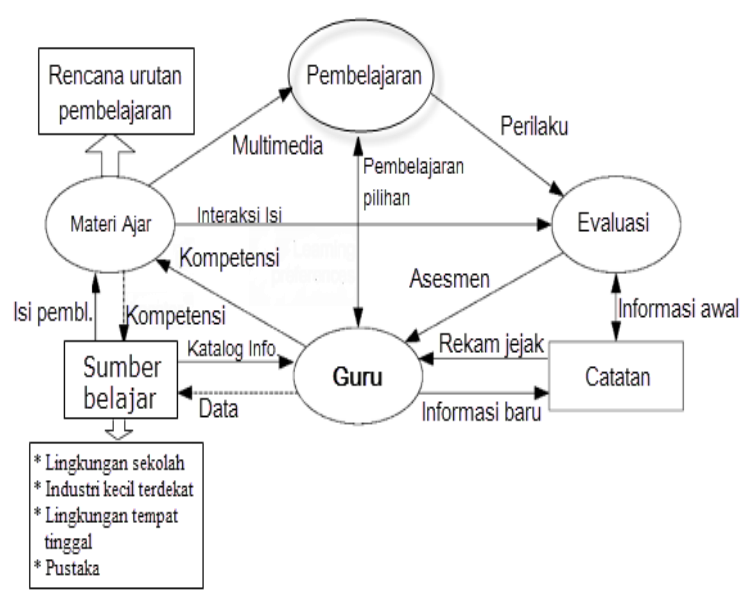

Gambar 3. Model Pembelajaran CTL 
Tabel 5. Deskripsi Data Nilai keterampilan menggambar 2D menggunakan Inventor

\begin{tabular}{|c|c|c|c|}
\hline \multicolumn{4}{|c|}{ Statistics } \\
\hline & & Pretest 2D & Posttest 2D \\
\hline \multirow[t]{2}{*}{$\mathrm{N}$} & Valid & 14 & 14 \\
\hline & Missing & 0 & 0 \\
\hline \multicolumn{2}{|l|}{ Mean } & 84.6429 & 85.3571 \\
\hline \multicolumn{2}{|c|}{ Std. Error of Mean } & 2.33313 & 1.10745 \\
\hline \multicolumn{2}{|l|}{ Median } & 85.0000 & 85.0000 \\
\hline \multicolumn{2}{|l|}{ Mode } & $74.00^{\mathrm{a}}$ & $85.00^{2}$ \\
\hline \multicolumn{2}{|c|}{ Std. Deviation } & 8.72976 & 4.14371 \\
\hline \multicolumn{2}{|l|}{ Variance } & 76.209 & 17.170 \\
\hline \multicolumn{2}{|l|}{ Skewness } & -.012 & -.145 \\
\hline \multicolumn{2}{|c|}{ Std. Error of Skewness } & .597 & .597 \\
\hline \multicolumn{2}{|l|}{ Kurtosis } & -1.690 & -1.509 \\
\hline \multicolumn{2}{|c|}{ Std. Error of Kurtosis } & 1.154 & 1.154 \\
\hline \multicolumn{2}{|l|}{ Range } & 21.00 & 10.00 \\
\hline \multicolumn{2}{|l|}{ Minimum } & 74.00 & 80.00 \\
\hline \multicolumn{2}{|l|}{ Maximum } & 95.00 & 90.00 \\
\hline \multicolumn{2}{|l|}{ Sum } & 1185.00 & 1195.00 \\
\hline \multirow[t]{3}{*}{ Percentiles } & 25 & 74.0000 & 80.0000 \\
\hline & 50 & 85.0000 & 85.0000 \\
\hline & 75 & 95.0000 & 90.0000 \\
\hline
\end{tabular}

Hasil pengamatan pada proses pembelajaran dengan penerapan model pembelajaran CTL terhadap hasil belajar siswa diperoleh adanya peningkatan prestasi. Hal tersebut dapat dilihat dari nilai rata-rata satu kelas pada hasil pembelajaran. Pada kompetensi membuat dan memodifikasi gambar 3D, nilai rata-rata siswa pada pretest sebesar 71.18, dan pada tahap postest nilai rata-rata siswa meningkat menjadi 84.64 atau sebesar $19 \%$. Pada kompetensi menyajikan gambar detail komponen mesin, nilai rata-rata pada pretest sebesar 68.75, meningkat menjadi 85.36.

Dari penjumlahan kedua kompetensi tersebut dengan bobot $40 \%$ kompetensi membuat dan memodifikasi gambar 3D + (ditambah) $60 \%$ kompetensi menyajikan gambar detail komponen mesin diperoleh hasil kompetensi siswa dalam menggambar dengan sistem CAD. Maka pada kompetensi menggambar dengan sistem CAD nilai rata-rata pada pretest sebesar 60.72, pada tahap posttest nilai rata-rata siswa kembali meningkat menjadi 85.07. Adapun peningkatan hasil belajar siswa dapat dilihat pada grafik berikut.
Pada kompetensi membuat dan memodifikasi gambar 2D, persentase kelulusan siswa pada pretest sebesar $29 \%$, dan pada posttest persentase kelulusan siswa menurun menjadi $71 \%$. Pada kompetensi menyajikan gambar detail komponen mesin, persentase kelulusan siswa pada awal sebesar 7\%, dan pada tahap akhir persentase kelulusan siswa kembali meningkat menjadi 100\%

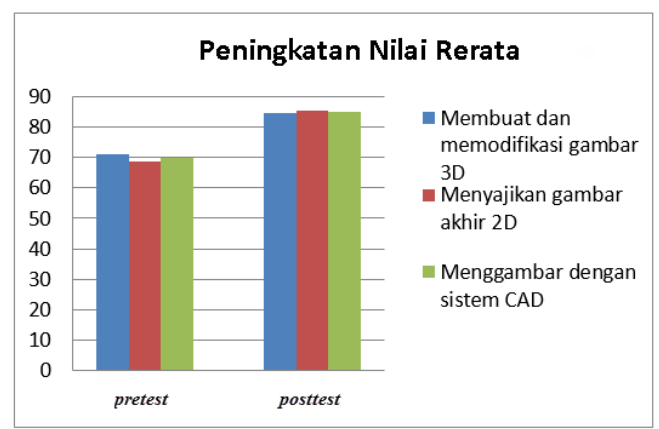

Gambar 4. Peningkatan Rerata Nilai Siswa

Pada kompetensi menggambar dengan sistem CAD persentase kelulusan siswa pada awal sebesar 29\% dan pada tahap akhir persentase kelulusan siswa kembali meningkat menjadi $100 \%$. Adapun peningkatan hasil belajar siswa dapat dilihat pada Gambar 5 .

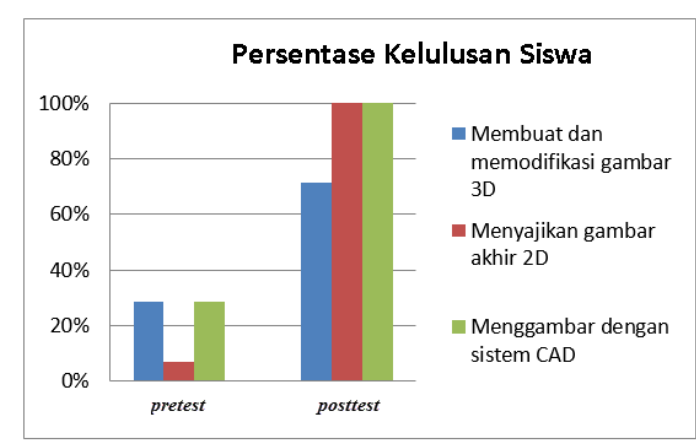

Gambar 5. Persentase Kelulusan Siswa

Sementara berdasarkan rerata nilai $2 \mathrm{D}$, nampak selisih yang yang kurang nampak yaitu 84 menjadi 85. Perbedaan ini menunjukkan bahwa keterampilan membuat obyek 3D tidak otomatis meningkatkan kemampuan dalam mempresentasikan gambar 2D. Hal ini perlu menjadi kajian tersendiri, karena gambar 2D jika yang diharapkan berupa gambar kerja teknik mesin haruslah memenuhi prasyarat atau 
kaidah gambar kerja. Lebih jauh dapat pula dikatakan bahwa kemampuan menerapkan kaidah gambar haruslah menjadi prasyarat untuk menempuh CAD. Namun di SMK tidak ada pelajaran prasyarat, maka diperlukan pelajaran pengayaan atau remedial khusus untuk pelajaran gambar teknik jika masih jauh dari nilai KKM.

\section{SIMPULAN}

Berdasarkan hasil penyajian data dan pembahasan tersebut menunjukkan bahwa: (1) Hasil uji coba pada skala besar menunjukkan bahwa modul CAD layak untuk diterapkan dalam uji coba pembelajaran CAD. Modul mendapatkan kategori respons sangat layak dari siswa untuk aspek fungsi dan manfaat dengan jumlah skor rerata 24,42. Modul mendapatkan kategori respons sangat layak dari siswa untuk aspek kemenarikan dengan jumlah skor rerata 37,73. Modul mendapatkan kategori respons sangat layak dari siswa untuk aspek materi pembelajaran dengan jumlah skor rerata 30,70.

(2) Metode pembelajaran CAD dapat ditempuh dengan urutan sebagai berikut: (a) menentukan KD, (b) menentukan materi, (c) menentukan benda atau obyek, (d) memotivasi dengan mengaitkan materi ajar dengan konteks lingkungan, (e) penentuan kelompok heterogen, pemberian tugas, (f) diskusi kelompok, (g) tugas mandiri, (h) penilaian, (i) refleksi hasil dan umpan balik. (3) Pembelajaran CAD menggunakan modul berbasis CTL dapat meningkatkan prestasi sebesar $19 \%$, atau dari 71.18, menjadi 84.64. Namun untuk materi 2D tidak ada perbedaan prestasi.

\section{DAFTAR RUJUKAN}

Coats, M. (2005). Action Research A Guide for Associate Lecture. New York: COBE.

Dick, W., Carey, L., \& Carey, J.O. (2015). The Systematic Design of Instruction. New York: Pearsons

Gall, M., Borg, W.R., \& Gall, J.P. (2003). Educational Research: An Introduction. New York: Allyn \& Bacon

Johnson, E.B. (2002) Contextual Teaching and Learning: What It Is and Why It's Here to Stay. California : Corwin Press. diakses dari https://books.google.co.id/

Lieu, D.K. \& Sorby, S. (2009). Visualization, Modeling, and Graphics for Engineering Design. New York: Delmar.

Paulus Rudolf Yuniarto. (2014). Masalah Globalisasi di Indonesia: Antara Kepentingan, Kebijakan, dan Tantangan. Jurnal Kajian Wilayah, Vol. 5, No. 1, hal. 67-95. 